\title{
Rat Adrenal Gland Pheochromocytoma
}

National Cancer Institute

\section{Source}

National Cancer Institute. Rat Adrenal Gland Pheochromocytoma. NCI Thesaurus. Code C121568.

A benign or malignant neuroendocrine neoplasm of the rat sympathetic nervous system that secretes catecholamines. It arises from the chromaffin cells of the rat adrenal medulla. 